\title{
THE LOCAL VENTILATION SYSTEM COUPLED WITH THE INDIRECT GREEN FAÇADE: A PRILIMINARY STUDY
}

\author{
T. ŠUKLJE, C. ARKAR \& S. MEDVED \\ Faculty of Mechanical Engineering, University of Ljubljana, Slovenia.
}

\begin{abstract}
Green façades are becoming an important architectural element in an urban environment. Regarding the technology of the installation of green façades, one can distinguish between direct and indirect green façades, living walls and double skin façades with foliage. In addition to aesthetics of green façades, an impact on the outdoor and the indoor comfort has been proven. That is due to changed temperature and air flow conditions at the building envelope boundary. It has been proven that green façades impact lower surface temperatures of a building envelope and enhance thermal insulation properties of a building envelope, thus reducing the energy demand of a building. Based on the results from green façade thermal response research and growing interest in local ventilation systems, one can conclude that there is potential for a free cooling of a building. Therefore, this paper presents the design and the preliminary experimental research of a local ventilation system coupled with an indirect green façade. Based on the experimental work, it has been ascertained that the indirect green façade can impact a $5 \mathrm{~K}$ lower inlet air temperature for the local ventilation system compared with the one at the traditional façade.
\end{abstract}

Keywords: Free cooling, green façade, local ventilation, vertical greenery.

\section{INTRODUCTION}

The greenery has been part of cities for centuries, it made landscape versatile and appealing to the residents. Nowadays, importance of greenery in urban environments is even increased due to its impact on the mitigation of the heat island effect [1,2]. In addition, greenery on the building envelope can impact lower cooling demand of the building itself. Greenery can be either applied to a roof or a vertical building envelope. The latter enables for greater energy savings as it presents the marginal share of the building envelope surface in urban environments. Due to the various architectural approaches, one can distinguish between direct and indirect green façades, living walls and double skin façades with foliage [3].

The greenery affects the temperature and flow conditions at the building envelope boundary through the process of evaporative cooling, the selective absorption of short-wave radiation and the shading of a building envelope [4]. The thermal response of green façades is frequently evaluated with field measurements of the temperature in consecutive layers from the building envelope surface towards the surroundings.

Such an investigation was carried out by Wong et al. [5] on free walls with the vertical greenery in the Tropical climate. The results show maximum reduction of $11.5^{\circ} \mathrm{C}$ in the wall surface temperature on a clear day. Which can, according to results from numerical simulations, result in reduction of cooling load up to $20 \%$ [6].

Besides lower surface temperatures, the foliage impacts lower air temperatures in the intermediate space, enclosed by the building envelope and the foliage. Due to the specific air-flow [7], temperature and humidity [8] conditions, the intermediate space can be addressed as the microclimatic layer at the building envelope boundary. Based on the experimental study, Šuklje et al. [8] reported maximum reduction of $4.3^{\circ} \mathrm{C}$ in the microclimatic layer temperature of the indirect green façade compared with the bare wall on clear summer day in the Continental climate. Whilst results from all-year field measurements of microclimatic layer temperatures show on average around ambient temperature in peak cooling season in Mediterranean climate [9]. 
Based on results from green façade thermal response research and growing interest in local ventilation systems, due to the higher energy efficiency and the comfort in comparison to centralized systems [10], one can conclude that there is potential for a free cooling of the building. An idea of the greenery as a cooling system for buildings has already been reported. In particular, Sheweka and Mohamed [11] designed a ventilation system combined with double-skin façade with plants. However, such a system cannot be efficient as it has been experimentally proven that plants in a double-skin façade cannot prevent overheating of the air cavity and are not likely to withstand the sever heat [12]. Therefore, the cooling potential could lie in a local ventilation system coupled with an indirect green façade.

In the present paper, a preliminary experimental study of cooling potential of an innovative system is presented. Field measurements of inlet air temperatures of the local ventilation system coupled with the indirect green façade system are carried out simultaneously with a traditional local ventilation system in order to allow for the determination of the temperature difference. Data are then processed with statistical methods and results discussed with respect to the previous research.

\section{THE EXPERIMENT}

Field measurements were carried out on the outside test facility (Fig. 1) that was designed with respect to the experience and findings from the previous research on the thermal response of the indirect green façade [8]. The south orientated test facility envelope was divided into two equal surfaces; on the right side, the indirect green façade was installed, meanwhile the other half was used as the referential façade. Façades were installed on the concrete floor in order to simulate urban environment conditions (Fig. 1).

For the indirect green façade, fast-growing Phaseolus vulgaris $L$ was chosen. The greenery was planted in containers aside the supporting structure with the low thermal mass. The plant was irrigated with respect to the calculated evapotranspiration using empirical relations [13].

The design of the indirect green façade allowed us to insert an air inlet collector of the local ventilation system in the air cavity, which is formed due to the offset of the vertical greenery with respect to the test facility envelope (Fig. 1). To ensure comparison, the same air inlet collector was also installed at the referential façade. The perforated bottom of the air inlet collector was designed
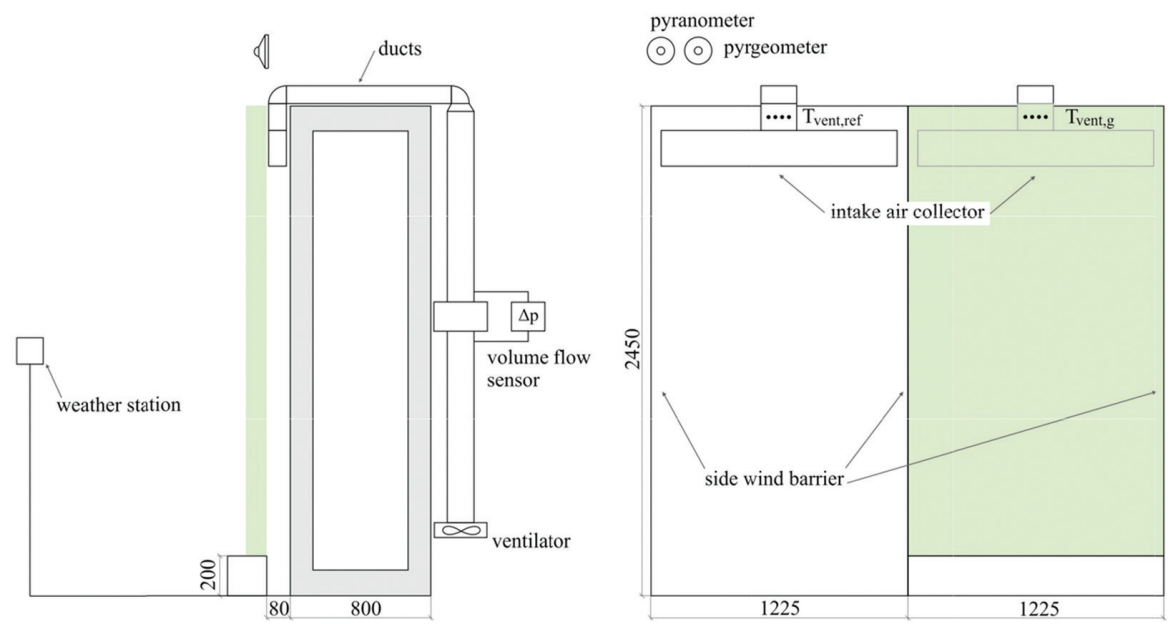

Figure 1: Scheme of the experimental setup. The side view (left) and the front view (right). 

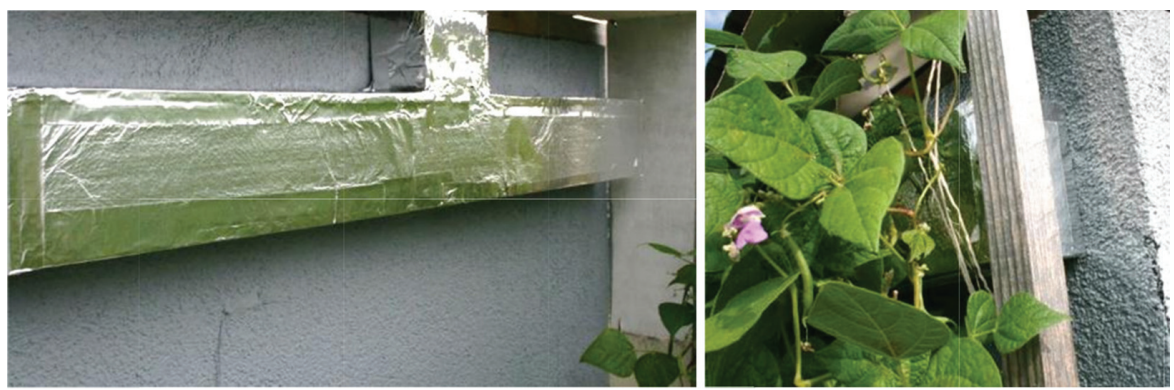

Figure 2: The air inlet collector (left); the air inlet collector inserted in the air cavity (right).

in such a way to ensure even air velocity on the entire length of the air inlet collector. Air inlet collectors and ducts were insulated and covered with aluminium foil (radiation shield) to prevent heat gains from the ambient (Fig. 2).

The air was driven vertically along the test facility envelope, through the perforation of air inlet collectors, through ducts to the backside of the test facility, where an air volume flow was measured, and finally discarded through ventilators to the ambient.

The sensor distribution on the test facility is outlined in Fig. 1. Global solar radiation on the vertical surface was measured with pyranometer Kipp \& Zonen SMP11 (non-linearity $\pm 1 \%$, temperature dependence $\pm 5 \%$ ). Pyrgeometer Kipp \& Zonen CG1 (non-linearity $\pm 1 \%$, temperature dependence $\pm 2 \%$ ) was used for measurements of the downward long wave radiation. The ambient temperature $( \pm 0.5 \%)$, relative humidity $( \pm 2 \% \mathrm{RH})$ and the wind velocity $( \pm 0.2 \mathrm{~m} / \mathrm{s})$ were measured in the weather station at the height of $1.25 \mathrm{~m}$ in front of façades. The used thermocouples for the inlet air temperature measurement were type- $\mathrm{T}$ with a measurement uncertainty of $\pm 0.25 \mathrm{~K}$. The volume flow meter operates on the principle of the damping method with a measurement uncertainty of $\pm 5 \%$. All sensors were properly calibrated before the installation in the experimental setup (Fig. 1) and then connected to data acquisition units AHLBORN Almemo 2290-8 in Agilent 34970A capturing data every $30 \mathrm{~s}$.

\subsection{Weather conditions}

Measurements were carried out in September 2013. In the present paper only preliminary study results from 6th to 8th September 2013 are presented and further analysed.

The main meteorological data, recorded during analysed days, are characterised by an ambient temperature $T_{a m b}$, with peaks reaching $27^{\circ} \mathrm{C}$. Global solar radiation on vertical surface $\mathrm{G}_{\mathrm{glob}, 90}$ reaching $740 \mathrm{~W} / \mathrm{m}^{2}$ and recorded wind velocities $v_{\text {wind }}$ up to $3 \mathrm{~m} / \mathrm{s}$.

\section{RESULTS AND DISCUSSION}

In the precedent experimental study, it has been ascertained that the vertical greenery reduces air temperatures at the building envelope boundary. Whilst in the present study, the vertical greenery system has been upgraded with the local ventilation system to improve the summer thermal comfort in buildings.

The air volume flow for the local ventilation system was set to $37 \mathrm{~m}^{3} / \mathrm{h} \mathrm{m}^{2}$ of the indirect green façade for all measurements. The rate was chosen based on the recommendations for the required fresh air supply for one person. 


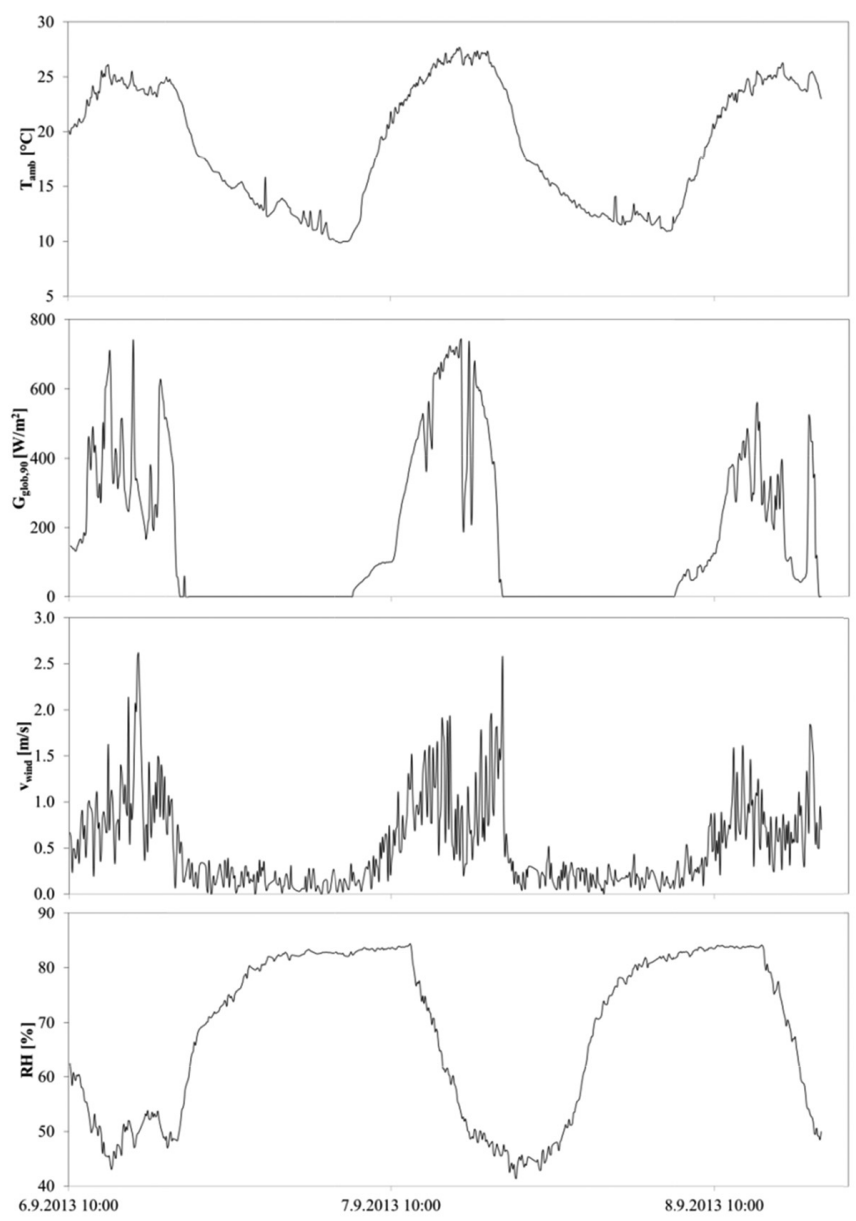

Figure 3: Measurements of meteorological parameters. From top to bottom: ambient temperature, global solar radiation, wind velocity and relative humidity.

Measurements of the inlet air temperature reduced for the ambient temperature are shown in Fig. 4. It can be ascertained that at day time, inlet air temperatures at the indirect green façade are up to $5 \mathrm{~K}$ lower than those at the referential façade. Nevertheless, based on the previous research on the thermal behaviour of green façades, one would expect lower inlet air temperatures at the indirect green façade. Due to the drought and extremely high temperatures in summer 2013, one should note that greenery was potentially thinned and worn out.

At night time, inlet air temperatures are the same except after the sunset where temperatures at the indirect green façade are slightly higher due to the reduced long-wave radiation heat flux to the surroundings.

Further analysis of the measured data reveals that at certain spikes, inlet air temperatures at referential façade are even lower than those at the indirect green façade. Therefore, measured inlet air temperatures were compared with the meteorological data and it has been noticed that lower inlet air 


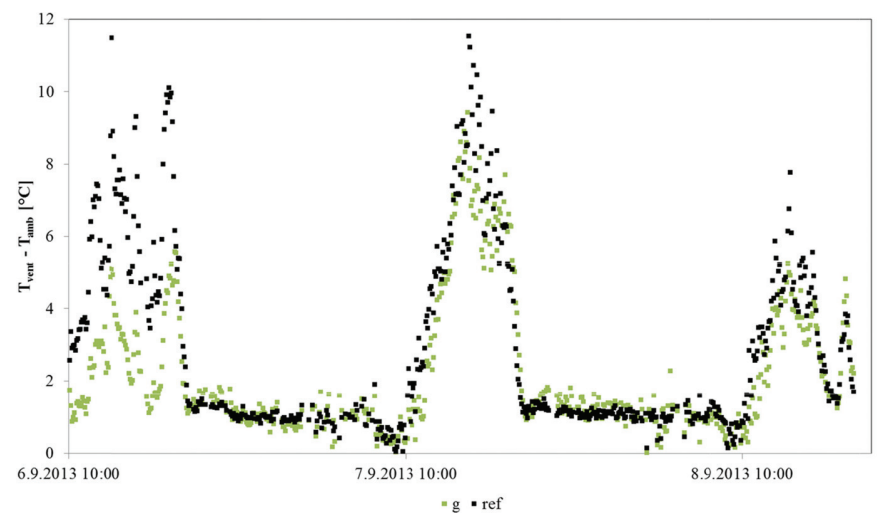

Figure 4: Measurement of the temperature difference on the inlet air temperature and the ambient temperature.

temperatures at referential façade coincide with wind velocity spikes. To confirm the observed correlation, a statistical analysis was performed.

\subsection{Statistical analysis}

The recorded day time data were analysed with the multiparametrical linear regression. The day time was limited with global solar radiation $G_{\text {glob,90 }}$ greater than $100 \mathrm{~W} / \mathrm{m}^{2}$. The temperature difference between the inlet air temperature and the ambient temperature was set as a dependent variable, whilst the global solar radiation, wind velocity and the relative humidity were set as independent variables in the following form:

$$
T_{\text {vent }}-T_{a m b}=b(0)+b(1) G_{g l o b, 90}+b(2) v_{\text {wind }}+b(3) \varphi
$$

The results of the multiparametrical linear regression are presented in Table 1. F-test and level of characteristics show that there is dependence of the inlet air temperature at the referential façade on the global solar radiation, the wind velocity and the relative humidity. Student's $t$-tests and the level of significance for the regression coefficients show that all regression coefficients are significantly different $(p<0.05)$. The results of the residue analysis indicate that residues are independent, distributed in a normal distribution with an average of 0 . All these statistical parameters show the suitability of the derived regression model. However, that cannot be concluded in the case of the indirect green façade. The results in Table 1 show that the wind velocity ( $p$-value $>0.05$ ) cannot be statistically related to the depended variable.

Based on the statistical analysis, one can conclude that observed lower inlet air temperatures at the referential façade compared with those at indirect green façade are indeed affected by the increase in the wind velocity. It is apparent that the air flow from the ambient is driven into the boundary layer at the test facility envelope. On the contrary, the phenomenon does not appear at the indirect green façade as the vertical greenery presents a wind barrier.

Based on the findings from the present study, thicker vertical greenery should be considered, in order to sustain lower temperatures in the microclimatic layer of the indirect green façade. To confirm the cooling potential of the presented system, the time frame of the measurement has to be extended. 


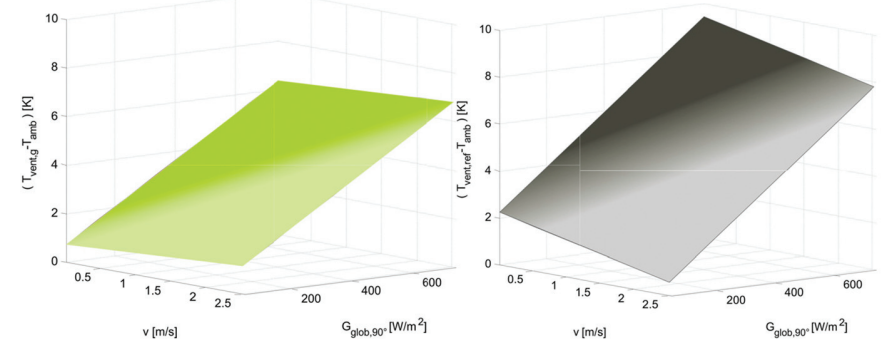

Figure 5: Response of the temperature difference to the wind velocity and the global solar radiation at the relative humidity $45 \%$ and specific volume flow rate $37 \mathrm{~m}^{3} / \mathrm{h} \mathrm{m}^{2}$ at the indirect green façade (left) and the referential (right).

Tabel 1: Results of the multiparametrical linear regression for the indirect green façade and the referential façade.

\begin{tabular}{|c|c|c|c|c|c|}
\hline & Coefficient & Value & Std. error & $t$-Statistics & $p$-Value \\
\hline \multirow{5}{*}{ 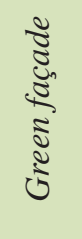 } & $b(0)$ & 13.218 & 1.162 & 11.37 & 0.0000 \\
\hline & $b(1)$ & 0.00383 & 0.000 & 6.90 & 0.0000 \\
\hline & $b(2)$ & 0.19276 & 0.179 & 1.07 & 0.2836 \\
\hline & $b(3)$ & 0.22324 & 0.020 & -11.17 & 0.0000 \\
\hline & $R^{2}=0.67$ & & & & \\
\hline \multirow{5}{*}{ 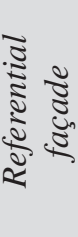 } & $b(0)$ & 14.286 & 1.3795 & 10.35 & 0.0000 \\
\hline & $b(1)$ & 0.00625 & 0.0007 & 9.46 & 0.0000 \\
\hline & $b(2)$ & 0.63579 & 0.2130 & 2.99 & 0.0031 \\
\hline & $b(3)$ & -0.21731 & 0.0237 & -9.16 & 0.0000 \\
\hline & $R^{2}=0.66$ & & & & \\
\hline
\end{tabular}

\section{CONCLUSION}

The article presents the preliminary experimental research on the thermal response of the local ventilation system coupled with the indirect green façade. The results highlight the cooling potential of the innovative system. It has been ascertained that coupling a local ventilation system with the indirect green façade results in up to $5^{\circ} \mathrm{C}$ lower inlet air temperatures during day time at the highest of the solar radiation and the ambient temperature. It also has been ascertained that the vertical greenery acts as a wind barrier at the building boundary, which coincides with the findings from other researchers. Combined with thinned greenery that reflects in the reduced cooling potential at wind velocity peaks due to the relatively high inlet air temperatures at the indirect green façade.

In the further research, it is necessary to consider a denser greenery as microclimatic layer temperatures are higher than ambient temperatures even though several researcher have reported the opposite. That can be beneficiary as lower temperatures of the microclimatic layer will reflect in greater cooling potential of the designed system. It is also mandatory to evaluate thermal response of the presented local ventilation system at higher specific volume flow rates and based on a 
parametrical analysis determine the optimal one. Future experimental studies ought to be performed at the peak of the cooling season with extended duration of measurements.

\section{REFERENCES}

[1] Vidrih, B. \& Medved, S., Multiparametric model of urban park cooling island. Urban Forestry \& Urban Greening, 12, pp. 220-229, 2013. doi: http://dx.doi.org/10.1016/j.ufug.2013.01.002

[2] Vidrih, B., Impact of Global Climate Changes and Urbanization on Local Climatic Condition in Cities. Ph.D. Thesis, Laboratory for Sustainable Technologies in Buildings, Faculty of Mechanical Engineering, University of Ljubljana, Ljubljana, 2011.

[3] Perini, K., Ottelé, M., Haas, E.M. \& Raiteri, R., Vertical greening systems, a process tree for green façades and living walls. Urban Ecosystems, pp. 1-13, 2012. doi: http://dx.doi. org/10.1007/s11252-012-0262-3

[4] Šuklje, T., Vidrih, B., Arkar, C. \& Medved, S., Bionic façade inspired by vertical greenery systems. 3rd international conference Central Europe towards Sustainable Building (CESB13). Prague, 2013.

[5] Wong, N.H., et al., Thermal evaluation of vertical greenery systems for building walls. Building and Environment, 45, pp. 663-672, 2010. doi: http://dx.doi.org/10.1016/j.buildenv.2009.08.005

[6] Wong, N.H., Tan, A.Y.K., Tan, Y.P. \& Wong, N.C., Energy simulation of vertical greenery systems. Energy and Buildings, 41, pp. 1401-1408, 2009. doi: http://dx.doi.org/10.1016/j.enbuild.2009.08.010

[7] Perini, K., Ottelé, M., Fraaij, A.L., Haas, E.M. \& Raiteri, R., Vertical greening systems and the effect on air flow and temperature on the building envelope. Building and Environment, 46, pp. 2287-2294, 2011. doi: http://dx.doi.org/10.1016/j.buildenv.2011.05.009

[8] Šuklje, T., Medved, S. \& Arkar, C., An experimental study on a microclimatic layer of a bionic façade inspired by vertical greenery. Journal of Bionic Engineering, 10, pp. 177-185, 2013. doi: http://dx.doi.org/10.1016/s1672-6529(13)60213-9

[9] Pérez, G., Rincón, L., Vila, A., González, J.M. \& Cabeza, L.F., Behaviour of green facades in Mediterranean Continental climate. Energy Conversion and Management, 52, pp. 1861-1867, 2011. doi: http://dx.doi.org/10.1016/j.enconman.2010.11.008

[10] Poredoš, P., Šuklje, T., Medved, S. \& Arkar, C., An experimental heat-transfer study for a heatrecovery unit made of corrugated tubes. Applied Thermal Engineering, 53, pp. 49-56, 2013. doi: http://dx.doi.org/10.1016/j.applthermaleng.2013.01.004

[11] Sheweka, S.M. \& Mohamed, N.M., Green facades as a new sustainable approach towards climate change. Energy Procedia, 18, pp. 507-520, 2012. doi: http://dx.doi.org/10.1016/j.egypro.2012.05.062

[12] Fang, W, Xiaosong, Z., Junjie, T. \& Xiuwei, L., The thermal performance of double skin façade with Tillandsiausneoides plant curtain. Energy and Buildings, 43, pp. 2127-2133, 2011. doi: http://dx.doi.org/10.1016/j.enbuild.2011.04.021

[13] Kurnik, B., Louwagie, G., Erhard, M., Ceglar, A. \& Bogataj Kajfež, L., Analysing seasonal differences between a soil water balance model and in situ soil moisture measurements at nine locations across Europe. Environmental Modeling \& Assessment, 19, pp. 19-34, 2014. doi: http://dx.doi.org/10.1007/s10666-013-9377-z 